\title{
Economic Growth Of Post-Soviet Central Asian Countries: Can Microentrepreneurship Play A Role?
}

\author{
Wali I. Mondal, National University, USA
}

\begin{abstract}
The Union of Soviet Socialist Republics broke down in 1991 giving birth to 15 Newly Independent States. Soon after independence, all post-Soviet states engaged in reforming their economies by abandoning the Gosplan-style central planning. In their quest for economic growth, all 15 States formed trade unions; however, these trade unions did not lead to any significant regional growth. On the other hand, both group-based and individual microcredit operations, conducted through microfinance institutes succeeded in four out of the five post-Soviet Central Asian Countries. This paper analyzed 43 microfinance institutes in 4 post-Soviet Central Asian Countries and found that there was significant prospect for the development of microentrepreneurship in the region. In order to promote economic growth, the author recommends formation of a consortium of microfinance institutes in the region with membership of all five countries. Further studies are needed to ascertain the growth prospect of the post-Soviet Central Asian Countries through the development of microentrepreneurship.
\end{abstract}

Keywords: Central Asian Countries, USSR, Economic Integration, Microfinance Institutes, Microcredit, Microentrepreneurship, Consortium of Microfinance Institutes

\section{INTRODUCTION}

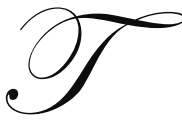

he break-up of the Union of Soviet Socialist Republics (USSR) in 1991 created 15 independent states, known variously as Post-Soviet States or the Newly Independent States (NIS). Based on geographic proximity, regional history and cultural traits, these 15 states are divided into the following five groups (http://en.wikipedia.org/wiki/Former_Soviet_Republics):

Baltic: Estonia, Latvia, Lithuania

Central Asia: Kazakhstan, Kyrgyzstan, Tajikistan, Turkmenistan, Uzbekistan

Eastern Europe: Belarus, Moldova, Ukraine

Eurasia: Russia

Transcaucasus: Armenia, Azerbaijan, Georgia

Until its break-down in 1991, the economy of the USSR was controlled by the Gosplan or the State Planning Committee. Gosplan was established in 1921; initially, its role was advisory, with the primary objective being co-ordination of the economic plans of the Union Republics and the creation of the common Union plan. However, in 1925 Gosplan assumed the over-all responsibility of the Soviet economy and started creating annual economic plans, known as "control numbers". The annual economic plans were part of the five-year plans, which set targets for production and distribution of all goods and services within the USSR. Eventually, Gosplan failed to function as the body responsible for the economic development of the country, and economic collapse of the USSR became imminent. It is against this backdrop of economic stagnation or decline of the USSR that the NIS deserted the central planning philosophy and opted for market economies. After nearly two decades of becoming independent, the NIS are struggling to establish their individual and unique places in the global economy; however, each group of states is engaged in some form of economic integration as a means to promoting regional growth. The 
objective of this paper is to analyze the economic growth potentials of the post-Soviet Central Asian Countries with a particular reference to the growth of Microentrepreneurship in the region.

\section{THE ECONOMY OF THE POST-SOVIET CENTRAL ASIAN COUNTRIES IN THE INITIAL YEARS}

Like most of the NIS, the post-Soviet Central Asian Countries began their transition to market economy in 1990-1991 with a goal to rebuilding and restructuring their economic systems. The transition however, was painful with Gross Domestic Product (GDP) dropping by more than 40\% between 1990 and 1995 (The World Bank, 2002). This decline in GDP was much more intense than the 27\% decline that the United States suffered in the wake of the Great Depression between 1930 and 1934 (Kalikova \& Associates: http://www.k-a.kg/?nid=5\&value=6 : retrieved January 13, 2009). The dramatic decline of GDP led to a reconfiguration of the public finances of all NIS, which in turn led to reduced spending on health, education and other social programs. The international community came to the rescue of the NIS economies with an agenda of market reform which was received well by all NIS. As a result of these market reforms, and a massive infusion of foreign aid, the post-Soviet states began to recover and the GDP growth rate started to switch from the negative to the positive territory.

Table 1: Post-Soviet Central Asian Countries Change in Gross Domestic Product (GDP) in constant prices, 1991-2007

\begin{tabular}{|l|c|c|c|c|c|c|}
\hline \multicolumn{1}{|c|}{ Country } & $\mathbf{1 9 9 1}$ & $\mathbf{1 9 9 5}$ & $\mathbf{2 0 0 0}$ & $\mathbf{2 0 0 5}$ & $\mathbf{2 0 0 7}$ & Turnaround year* $^{* 1}$ \\
\hline Kazakhstan & 100.0 & 68.9 & 77.8 & 127.1 & 148.7 & 1996 \\
\hline Kyrgyzstan & 100.0 & 56.6 & 74.3 & 89.1 & 98.7 & 1996 \\
\hline Tajikistan & 100.0 & 43.5 & 50.0 & 78.2 & 89.5 & 1997 \\
\hline Turkmenistan & 100.0 & 65.4 & 79.8 & 167.4 & 188.9 & 1998 \\
\hline Uzbekistan & 100.0 & 82.5 & 93.6 & 117.2 & 132.0 & 1996 \\
\hline
\end{tabular}

*The year when GDP decline switched to GDP growth.

Source: IMF 2006; http://www.imf.org/external/pubs/ft/weo/2006/01/data/dbcselm.cfm?G=2001)

As Table 1 shows, the economies of the post-Soviet Central Asian countries started to turn around in 1996. Three of the five countries registered positive GDP growth in 1996, while Tajikistan, the poorest of the five countries did not register positive GDP growth until 1997. The economy of Turkmenistan, a country rich in natural resources took the longest time to turn around, ostensibly for political reasons. However, in recent years, the country has registered one of the highest GDP growths in the world. By 2007, two countries of the region, Kyrgyzstan and Tajikistan, could not reach the GDP level of 1991.

\section{THE QUEST FOR ECONOMIC GROWTH: ECONOMIC INTEGRATION}

Soon after the dissolution of the Soviet Union, all 15 states of the former USSR started to form regional organizations with a common goal - to foster regional economic growth. Understandably, most blocks of countries sought the presence of Russia as the strongest member of the block. The following description provides the endeavors of the post-Soviet Central Asian Countries to form partnership with contiguous states with a goal to cooperating economically.

- Commonwealth of Independent States (CIS): In 1991, three countries, Belarus, Russia and Ukraine founded the CIS with a goal to include all 15 former republics of the USSR. However, three Baltic States, Estonia, Latvia and Lithuania did not join the CIS and claimed to have retained their sovereignty which existed before the break-up of the USSR.

- $\quad$ Eurasian Economic Community: Belarus, Russia and Kazakhstan initiated the move to form a Trade Union called the Eurasian Economic Community (EAEC) in March 1996; however, the treaty was not signed until October 2000. Uzbekistan joined the Trade Union in October 2000. As of now, the four member states have eliminated visa requirement for free movement among themselves. Common economic space similar to the European Union may be launched in 2010. 
- Organization of Central Asian Cooperation: Originally founded by all five post-Soviet Central Asian Countries in 1991, the Organization of Central Asian Cooperation (OCAC) later included Georgia, Turkey and Ukraine as observers. The organization with strong emphasis on economic agenda was initially known as Central Asian Commonwealth (CAC). The organization continued under this name until 1994 when it changed its name to Central Asian Economic Union (CAEU) which resulted in the desertion of two member states: Tajikistan and Turkmenistan. In 1998, CAEC changed its name and charter into Central Asian Economic Cooperation (CAEC). This marked the return of Tajikistan; however, Turkmenistan did not return. Ostensibly, with the intervention of Russia and its joining the organization in May 2004, CAEC reverted back to Eurasian Economic Community (EAEC).

As the above description suggests, efforts at economic integration of the post-Soviet Central Asian Countries did not lead to any significant economic benefit of the member states. Almost two decades after achieving independence, most post-Soviet Central Asian Countries are still struggling to forge economic partnership to achieve economic growth at the grass-roots level. Since the mid-1990s, most of these countries adopted some version of micro-financing with the stated goal of promoting economic growth by offering collateral-free small-loans known as microcredit to the small and medium-size enterprises.

\section{MICROCREDIT: AN OVERVIEW}

The concept of collateral free microcredit originated in Bangladesh around the beginning of the $20^{\text {th }}$ century when Rabindranath Tagore founded the Kaligram Krishi (Agricultural) Bank in Patishar village in the district of Naogaon in 1905 (Mondal, 2002). Tagore represented a landlord family and introduced the five- member, groupbased microcredit program with a goal to helping the desperately poor peasants who were unable to pay the rental on the land they cultivated. The essence of microcredit program, as envisioned by Tagore, is the absence of physical collateral. The financing scheme allows the recipients to improve the status of their living through access to additional capital without collateral.

The original microcredit model required that a group of five individuals apply for a loan on behalf of one member. The group guaranteed repayment of a loan offered to one member at a time. Once a group member has paid off a loan, another member of the group may qualify for a new loan or a repeat loan may be granted to a nondefaulting client. The original model has gone through many transformations. In most countries, microfinance clients are typically self-employed and low-income entrepreneurs in both urban and rural areas. According to our survey, there were 43 non-bank financial intermediaries or Microfinance Institutes (MFI) operating in all Central Asian Countries except Turkmenistan in 2007. An average microloan to a group or an individual in these countries ranged from U.S. \$29 in Uzbekistan to \$171,473 in Kazakhstan.

Many studies suggest that since inception, microcredit programs have been able to reduce the incidence of extreme poverty. A World Bank study found that percentage of Grameen Bank, Bangladesh borrowers living in extreme poverty was reduced by 70 percent within 4.2 years of joining the group-based microcredit program (Latifee, 2000). Research conducted by the Consultative Group for the Poor in Indonesia found that microcredit borrowers increased their incomes by 12.9 percent compared to 3.0 percent by the incomes of non-clients. (http://www.sbp.org.pk/reports/quarterly/FY05/first/Special_2.pdf). Similar studies for the post-Soviet Central Asian Countries are yet to be undertaken.

\section{MICROCREDIT AND MICROENTREPRENEURSHIP}

The growth of MFIs and particularly their near perfect loan recovery rate has been accompanied by the development of a variety of loan products offered by individual MFIs. As a result, the number of borrowers increased manifold which in turn led to the development of new loan products. Borrowers of microcredit do not fall into the same category and in most instances, MFIs make a distinction of borrowers and offer differentiated loan products to different groups. For example, ASA (pronounced "Asha") an NGO in Bangladesh, offers two types of loans: small loan and small business loan. The size of the initial small loan is quite small and is comparable to similar microloans offered by other MFIs in the country. It is offered to landless women who do not own any asset and are defined to be very poor. On the other hand, the small business loan is significantly larger in size and is 
offered to an existing business. The existing business may need the additional capital to either expand its operation or to buy equipment for modernizing its product or to explore new markets for an existing product. Other resourceful MFIs also differentiate between borrowers along the same general line as ASA. Mondal (2002) classified the borrowers of MFIs as:

- Microborrowers

- Microentrepreneurs

The microborrowers demonstrate a willingness and ability to generate a steady flow of income through conventional sources such as trading or paddy husking. There is no significant risk involved in the income generating activities of the microborrowers. Their labor is the predominant input, which is supplemented by a stock of capital in the form of a microcredit. The microborrower's ability to repay the loan is evaluated jointly with other members of the group.

A microentrepreneur, on the other hand, usually owns a microenterprise and is engaged in innovating new ways of doing business or initiating changes in the production function, exploring market opportunities for his product and, ultimately changing the culture of doing business.

The operation of microfinancing activities through MFIs is a perfect blend of normative and positive economics. As Friedman (1935) suggests, normative economics uses value judgments in evaluating an economic outcome. In the present context of post-Soviet Central Asian Countries, microfinancing programs are specifically designed for the segment of population who are below a defined line of poverty, therefore, it is a normative analysis. Positive economics, on the other hand, is free of value judgments. The positive economics methodology requires that an economic problem and its solution be stated in terms of efficiency. Standards for microentrepreneurs are established on the basis of efficiency and thus may be considered as positive economic analysis.

The bulk of the microcredit goes to microborrowers. Through their operation, the microborrowers have not only done well for themselves, but also have contributed to the sustained growth of the poor economies and helped alleviate poverty in these economies. The contributions of the microentrepreneurs go far beyond generating a steady flow of income. They are agents of change. They innovate and open up new opportunities for others. In the context of post-Soviet Central Asian countries, the role of microcredit operation in creating a steady flow of income for its members, generating new employment opportunities, creating new markets and sources of supply, and above all, creating a class of microentrepreneurs cannot be overemphasized. In order to understand how the microentrepreneurs work as agents of change in a developing economy, a brief overview of the concept of entrepreneurship is presented in the following section.

Private means of production ultimately leads to innovation and assumption of risk. These two phenomena, innovation and risk-taking are associated with entrepreneurship. The term "entrepreneur" was first introduced in the Mercantilist age by Richard Cantillon (1680-1734). Schumpeter (1950) noted "Cantillon's work, which is usually, though not quite correctly described as the first systematic treatise on economics, then introduced the term "entrepreneur". Cantillon defined an entrepreneur as the agent who buys means of production at certain prices in order to combine them into a product that he is going to sell at prices that are uncertain at the moment at which he commits himself to his costs". (pp 253-54). The idea thus developed by Cantillon was incorporated into Say's Treatise on Political Economy (1821). Say defined an entrepreneur as an agent who combines other resources into a "productive organism". He also used the term to indicate shifting of resources from a lower productive state to a higher productive state. It is important to note that Say did not incorporate the element of risk in his analysis of entrepreneurship although Cantillon alluded to it. Later, John Stuart Mill developed the concept further and associated entrepreneurship with activities involving risk and profit (Mill, 1871).

Although Mill incorporated risk in his analysis of profit and linked it to entrepreneurship, he, in fact was using the terms "entrepreneur" and "capitalist" synonymously. It appears that during most of the later nineteenth century, the two terms were used synonymously. Joseph Schumpeter is the first economist who distinguished between an entrepreneur and a capitalist (Schumpeter, 1939, 1950). According to him, assumption of risk involving innovation is the role of the entrepreneur, while assumption of risk involving potential for profit is the role of a 
capitalist. Both an entrepreneur and a capitalist undertake risk; but their domains are separate. Individuals who own business and take risk with their capital in pursuit of profit, but do not innovate, are capitalists. There are individuals who take risk by introducing a new product, adopting a new production process, creating new markets, introducing new technology or creating a new economic organization. Schumpeter referred to these individuals as "entrepreneurs" who belong to a "distinct sociological class". According to him, the process of discovery and innovation modifies the past and creates new opportunities for the creation of wealth in the future. This is what Schumpeter described as the process of "creative destruction".

According to Schumpeter, "the function of entrepreneur is to reform or revolutionize the pattern of production by exploiting an innovation or, more generally, an untried technological possibility for producing a new commodity or producing an old one in a new way, by opening up a new source of supply of materials or a new outlet for products, by reorganizing an industry". At the heart of Schumpeter's analysis is innovation, which is accompanied by risk assumed by an entrepreneur. He went on to attribute innovation as the business activity that brings about a new production function as a result of one or more of the following five economic activities:

1. introduction of a new good

2. adoption of new inputs to produce a new good or the previously produced good

3. introduction of new technology

4. $\quad$ opening of a new market; and

5. creating a new economic organization.

A brief description of entrepreneurial activities related to the Schumpeterian model is presented below.

The introduction of a new good: Arguably this is the most important activity of an entrepreneur pertaining to the change in a production function. An entrepreneur seizes the opportunity to introduce a new product in the market that is currently not available to the consumer. In the context of post Soviet Central Asian Countries, particularly in a new and emerging market, introduction of a new good has the prospect of maximum return to an entrepreneur.

The introduction of a new method of production: This refers to changing technological relationship or the existing production function. In order to lower the per unit cost of production, an entrepreneur may introduce a new method of production or substitute new and cheaper inputs in place of the existing inputs. If an entrepreneur is successful in doing this, she or he will ensure the maximum profit from the sale of a new product. In the context of post-Soviet Central Asian Countries, where labor is abundant, microentrepreneurs may look for substituting more labor for capital in devising newer methods of production.

The opening of a new market: This is one of the two functions of innovation. Once a product has been developed with the least cost method of production, an entrepreneur looks for a new market. In the context of post-Soviet Central Asian Countries, with an ever-growing population leading to unmet demands, finding a market does not seem to be a problem for an entrepreneur.

The conquest of a new source of supply of a raw material: This is the second function of innovation. Because resources are scarce, new source of supply of raw materials is an important factor in ensuring continuous supply of a newly developed product. In the context of post-Soviet Central Asian Countries, particularly where capital is scarce, a microentrepreneurs search for new sources of supply of raw materials may lead to innovation in the market place.

The carrying out of a new organization of an industry: In describing the innovation as the final process of changing a production function, Schumpeter related this process of innovation to breaking into a monopoly market. The emerging microfinance industry of post-Soviet Central Asian Countries is an example of a new organization of the banking industry. A number of commercial banks of post-Soviet Central Asian Countries have opened up new departments for microcredit similar to the MFIs.

Schumpeter's theory of entrepreneurship stimulated extensive writing on the subject. Numerous studies have supported various sets of personality characteristics based on certain assumptions about behavior where sets of criteria, traits and personal principles and characteristics provide different types of insight. An approach now gaining 
more popularity explains entrepreneurship by combining economic, personal, and sociological variables. Personal characteristics, such as the need for achievement, risk-taking propensity, locus of control, beliefs about wealth and material gain, and business growth are related to a person's predisposition toward business leadership (Gartner, 1990, McDaniel, 2002). A belief that a person can influence his or her personal destiny and locus of control distinguishes entrepreneurs from the general population. The microentrepreneurs possess the traits and characteristics of the "distinct sociological class" described by Schumpeter.

Much discussion took place on the role of an entrepreneur in developed and developing economies after the work of Schumpeter, particularly by Sweezy (1943), Leontief (1937), Angell (1941), Wright (1947), Lange (1943), Rostow (1948) and McDaniel (2002). The debate usually centered on the role of entrepreneurship in invention and innovation. More importantly not much has been done in relation to a developing economy. Although Rostow provided the theory of stages of economic growth, much of his theory came under close scrutiny in the latter half of the twentieth century particularly with the onset of service economy. Many developing economies showed signs of prosperity through proper planning of their manpower and surplus labor. The globalization of the world economy speeded up the process of integration of both developed and developing economies.

In reality, Schumpeter's model works through the transformation of a production function. A production function refers to the methods and processes by which the factors of production namely land, capital and labor are combined by an entrepreneur for tangible output. This is where Schumpeter made a distinction between the terms invention and innovation. According to him, invention is discovery of new ideas, concepts, or material items that are normally confined to speculative reasoning. Such reasoning can be abstract and may remain uninvestigated in a scientific laboratory; however, if an invention in the form of an idea or a material item is transferred to the business sector with a view to changing the production function, then it becomes innovation. Using microcredit, microentrepreneurs of many developing countries, notably Bangladesh, have been able to transform their existing businesses to other organizational forms which use intermediate technology or advanced technologies. Since becoming independent, most post-Soviet Central Asian Countries have adopted both the original group-based microcredit model as well as single borrower model. Table 2 below shows the number of MFIs in each post-Soviet Central Asian Country along with the average loan size and the existence of large size loans for single borrowers.

Table 2: MFIs in Post-Soviet Central Asian Countries

\begin{tabular}{|l|c|c|c|c|c|}
\hline \multicolumn{1}{|c|}{ Country } & $\begin{array}{c}\text { Per Capita GDP, } \\
\text { 2009, U.S. \$ } \\
\text { (cons. prices) }\end{array}$ & Number of MFI & $\begin{array}{c}\text { Average Loan } \\
\text { Size U.S. \$ }\end{array}$ & $\begin{array}{c}\text { Group (G), } \\
\text { Individual (I) } \\
\text { Loan }\end{array}$ & $\begin{array}{c}\text { Large Individual } \\
\text { Loans }\end{array}$ \\
\hline Kazakhstan & 8719 & 13 & 18,977 & G, I & Yes \\
\hline Kyrgyzstan & 2184 & 16 & 2,161 & G, I & Yes \\
\hline Tajikistan & 2022 & 11 & 616 & G, I & No \\
\hline Turkmenistan & 5756 & N.A. & N.A. & N.A. & N.A. \\
\hline Uzbekistan & 1026 & 3 & 1,011 & G, I & No \\
\hline
\end{tabular}

As Table 2 shows, 4 of the 5 post-Soviet Central Asian Countries have a good program of microcredit operation with both individual and group-based loans offered to clients. The average loan size for all countries is significantly higher than many regions of the world. For example, in a study on the Sub-Saharan Africa, Mondal (2009) found that out of 48 countries in the region, the average loan size of 40 countries was below U.S. 1,000 which was not conducive to the growth of microentrepreneurship. In comparison, in 32 out of 43 MFIs in postSoviet Central Asian Countries the average loan size was over $\$ 1,000$. Kazakhstan being the richest country of the region had an average loan size of $\$ 18,977$ which was ideal for the growth of microentrepreneurship. Remarkably, all 4 countries had programs of group-based and individual loans. It is unclear, however, why Turkmenistan, being the second richest country of the world, did not have any program of microfinancing until 2007. One prospect of regional growth in the post-Soviet Central Asian Countries which has not been investigated is the formation of consortium of MFIs among member states with a goal to increase investment opportunities among the member states. 


\section{SUMMARY AND CONCLUSIONS}

After breaking up from the USSR in 1991, the 15 newly independent states formed a number of trade unions with a goal to promoting economic growth among themselves. The trade unions did not promote economic growth for a number of reasons. On the other hand, in four of the five post-Soviet Central Asian Countries, significant growth of microcredit operation took place. The microfinance institutes, which lend to group-based and individual borrowers, have been making relatively large size loans, ideal for the growth of microentrepreneurship. Given the large size of loans of most MFIs in the region, the paper proposes formation of consortium of MFIs among member states with a goal to increase investment opportunities among the member states. Such a consortium may result in enhanced co-operation between all five post-Soviet Central Asian Countries including Turkmenistan.

\section{AUTHOR INFORMATION}

Dr. Wali I. Mondal is a Professor of Business at National University in La Jolla, California where he also served as Interim Dean during 2006-07 and 2007-08 academic years. Mondal received his Ph.D. from the Ohio State University and has been a full time faculty for over 28 years. During 1993-96, he served as the Chair of the Department of Accounting, Economics and Business Education at Henderson State University. He has published a scholarly book, book chapter and over 70 papers in national and international refereed journals. Professor Mondal is the founding President and Conference Chair of the American Society of Business and Behavioral Sciences (ASBBS www.asbbs.org ). He is also the Editor or Editor-in-Chief of 5 national and international journals.

\section{REFERENCES}

1. $\quad$ Angell, J.W. 1941. Investment Business Cycles. New York and London: McGraw-Hill.

2. Gartner, William B. 1990. "Who Are We Talking About When We Talk About Entrepreneurship?” Journal of Business Ventures, January: 15-28

3. Gladwin, C.H (ed). 1991. Structural Adjustment and African Women Farmers. Gainesville, FL: University of Florida Press.

4. International Monetary Fund IMF. 2006 http://www.imf.org/external/pubs/ft/weo/2006/01/data/dbcselm.cfm?G=2001

5. Kalikova \& Associates: http://www.k-a.kg/?nid=5\&value=6 : retrieved January 13, 2009

6. Lange, O. 1943. "A Note on Innovations." Review of Economic Statistics, February 1943: 19-25.

7. Latifee, H.I. 2000. Microcredit and poverty reduction; Experiences of Grameen operation in Asia. Dhaka, Bangladesh: Grameen Trust

8. McDaniel, Bruce. 2002. Entrepreneurship and Innovation: An Economic Approach. Armonk, New York: M.E. Sharpe.

9. Mills, John Stuart. 1848. Principles of Political Economy. London: Macmillan Press.

10. Mondal, Wali. 2009. "Poverty Alleviation and Microcredit in Sub-Saharan Africa". International Business and Economics Research Journal. Volume 8, Number 1: 1-10.

11. Mondal, Wali I. 2002. Microcredit and Microentrepreneurship. Collateral Free Loan at Work in Bangladesh. Dhaka, Bangladesh: Academic Press.

12. Mondal, Wali I and Ruth Ann Tune. 1993. "Replicating the Grameen Bank in North America: The Good Faith Fund Experience." In Abu N.M. Wahid, ed. The Grameen Bank

13. Rostow, W.W. 1948. British Economy of the Nineteenth Century. New York: Oxford University Press.

14. Say, J.B. 1821. A Treatise on Political Economy. (Transaled by C.R. Princep). Boston: Wells and Lilly (originally published in 1803).

15. Schumpeter, Joseph A. 1950. Capitalism, Socialism and Democracy. New York: Harper and Sons.

16. 1939. Business Cycles: A Theoretical, Historical, and Statistical Analysis of the Capitalist Process. New York: McGraw-Hill.

17. 1936. The Theory of Economic Development: An Inquiry into Profits, Capital Credit, Interest and the Business Cycle. Cambridge, MA: Harvard University Press.

18. Sweezy, P.M. 1943. "Professor Schumpeter's Theory of Innovation". Review of Economic Statistics. February 1943: 93-96.

19. World Bank. 2002. World Development Report 2005. The International Bank for Reconstruction and Development, Washington, D.C. 


\section{INTERNET REFERENCES}

1. http://en.wikipedia.org/wiki/Former_Soviet_Republics

2. http://www.sbp.org.pk/reports/quarterly/FY05/first/Special_2.pdf

3. http://belfercenter.ksg.harvard.edu/publication/1805/managing_conflict_in_the_former_soviet_union.htm

4. http://www.jdc.org/p_fsu.html

\section{NOTES}

